\title{
Ovarian Membrane Receptors for LH, FSH and Prolactin during the Menstrual Cycle and in Polycystic Ovary Syndrome
}

\author{
Hirotaka Ota, Mineko Fukushima, Junji Murata, \\ Akira Wakizaka* and Masahiro Maki \\ Departments of Obstetrics and Gynecology and \\ * Biochemistry, Akita University School of Medicine, Akita \\ 010
}

Ota, H., Fukushima, M., Murata, J., Wakizaka, A. and Maki, M. Ovarian Membrane Receptors for LH, FSH and Prolactin during the Menstrual Cycle and in Polycystic Ovary Syndrome. Tohoku J. exp. Med., 1986, 149 (3), 231-240 To investigate the role of ovarian membrane receptors for LH, FSH and prolactin of patients with developing polycystic ovary (PCO) syndrome, seven patients were selected and the receptor function was studied in relation to changes of several serum hormone levels. The results were compared with those from individuals with regular menstrual cycles in the late follicular $(\mathrm{LF} ; n=6)$ and midluteal (ML; $n=6$ ) phases. LH receptor binding in the normal cycle remained low $(1.73 \pm 0.14 \mathrm{fmole} / \mathrm{mg}$ homogenate protein) in the LF phase and elevated 3 fold in the ML phase. LH receptors in the PCO patients maintained a higher binding level than that in the LF phase, being close to the ML level. FSH receptors were at a high level in the LF phase $(4.09 \pm 0.40 \mathrm{fmole} / \mathrm{mg}$ homogenate protein), but decreased by $23 \%$ in the ML phase. In the PCO group the ovarian FSH receptor showed a high level, near to that in the LF phase. Prolactin receptors showed no significant changes among the two controls and PCO group. PCO patients showed increased levels of serum $\mathrm{LH}$ and testosterone and a raised ratio of estrone to estradiol, although there was no change in the serum FSH level. These data suggested that the LH receptor binding in PCO was not so low as to the LF level. A lack of the down-regulation mechanism of $\mathrm{LH}$ receptors, in spite of the high level of serum LH in PCO, might be one of the clues to elucidate the pathophysiological mechanism in developing PCO syndrome. Elevated levels of the gonadotropin receptors, especially FSH receptors, seem to be involved in the high incidence of ovarian hyperstimulation during hormone treatment. —— polycystic ovary $(\mathrm{PCO})$; LH receptors; FSH receptors ; prolactin receptors ; human

For the understanding of the endocrinological mechanism in developing polycystic ovary ( $\mathrm{PCO}$ ) syndrome, it seems to be especially important to elucidate the function of ovarian membrane receptors for $\mathrm{LH}, \mathrm{FSH}$ and prolactin. In fact,

Received October 15, 1985; accepted for publication April 15, 1986.

Reprint requests : Hirotaka Ota, Department of Obstetrics and Gynecology, Akita University School of Medicine, 1-1-1 Hondo, Akita 010, Japan. 
we have occasionally encountered such clinical problems that PCO syndrome accompanies hyperprolactinemia (Thorner 1977; Ota et al. 1979; Tzingounis et al. 1979 ; Falaschi et al. 1980 ; Wortzman and Hirschowitz 1980). In these cases ovarian response to hormonal stimulation is reduced. While, some of patients with PCO are sensitive to gonadotropin treatment and PCO is liable to cause ovarian hyperstimulation, especially in those with borderline hyperprolactinemia (Dawood and Saxena 1978; Fukushima and Ota 1981). These findings may suggest that there would be some abnormal mechanism on receptor modulation in the PCO ovaries. Rajaniemi et al. (1980) reported that the ovarian LH receptor binding in PCO patients was lower than that in normal women with preovulatory follicles. Copmann and Adams (1981) observed an elevated level of FSH receptors in the experimentally produced PCO in hypothyroid rats by the continuous daily injection of hCG. They indicated that the elevated level of FSH analyze would be an important clue to analyze the pathophysiological mechanism in developing PCO. Our previous observation revealed (Ota et al. 1982a) that LH receptor binding in $\mathrm{PCO}$ rats produced by the administration of testosterone was much more elevated than the proestrus level. In the present study, we attempted to elucidate a role of the ovarian LH, FSH and prolactin receptors in PCO syndrome following the previous report (Ota et al. 1984).

\section{Materials and Methods}

\section{Hormones and chemicals}

For iodination, ovine prolactin (oPRL; $32 \mathrm{IU} / \mathrm{mg}$ ), human chorionic gonadotropin (hCG ; 9,600 IU/mg) and human FSH (NIAMDD-hFSH-2; FSH biopotency, 3,925 IU/mg; LH biopotency, $523 \mathrm{IU} / \mathrm{mg}$ ) were obtained from Sigma Co. (St. Louis, MO, USA), Teikoku Hormone MFG Co. (Tokyo) and NIH, NIADDK (Bethesda, MD, USA). The purity of oPRL was confirmed by gel electrophoresis (Ota 1983). In order to inhibit receptor bindings, hCG oPRL and ovine FSH (oFSH ; NIH FSH-S14; FSH potency, equal to 9 NIH FSH-S1 units/mg; LH activity, 0.02 NIH LH-S1 units/mg; PRL activity, $0.1 \%$ by weight) were used. Iodogen for the iodination was purchased from Pierce Co. (Rockford, IL, USA). Ultrogel AcA44 was obtained from LKB (France). Carrier free $\mathrm{Na}\left[{ }^{125} \mathrm{I}\right]$ (NEZ-033H) was purchased from New England Nuclear (Boston, MA, USA).

\section{Collection of human ovarian samples}

Seven PCO patients, aged from 24 to 32 years and weighing $52.7 \pm 2.4 \mathrm{~kg}$ in an average, participated and agreed to this study from the Department of Obstetrics and Gynecology at Akita University Hospital in Akita. These patients were selected on the basis of clinical, endocrinological and histological signs as described previously (Ota et al. 1979; Fukushima and Ota 1981). Six of them complained of secondary amenorrhea and responded to gestagen test. The remained patient showed an ovulatory cycle. Two of the patients were obese, exceeding $120 \%$ of their standard body weight. The control groups consisted of 12 women with regular ovulatory menstrual cycles ; 6 women showed late follicular (LF) phase (day 10 to 12 ) and the others showed midluteal (ML) phase (day 6 to 8 after ovulation). All of the controls had undergone surgical operations, correcting such problems as : uterine myoma, tubal ligation and unilateral ovarian cyst. Ovarian specimens, which were obtained by unilateral or bilateral ovarian wedge resection, were collected on ice, weighed and frozed quickly. They were stored at $-80^{\circ} \mathrm{C}$ until receptor assay. Part of the resected 
ovarian tissues were subjected to histological examination. On the day of operation, blood samples were obtained, and separated sera were stored at $-20^{\circ} \mathrm{C}$ until the assay.

Receptor binding assays for LH, FSH and prolactin

$\mathrm{hCG}, \mathrm{hFSH}$ and $\mathrm{oPRL}$ were iodinated with $\mathrm{Na}\left[{ }^{125} \mathrm{I}\right]$ by the method of Fraker and Speck (1978). The specific activities of the labeled $\left[{ }^{125} \mathrm{I}\right]$ iodo-hCG and $\left[{ }^{125} \mathrm{I}\right]$ iodo-hFSH and $\left[{ }^{125} \mathrm{I}\right]$ iodo-hPRL were ranged from 30 to $70 \mu \mathrm{Ci} / \mu \mathrm{g}$. The binding assays for gonadotropins and $\left.{ }^{125} \mathrm{I}\right]$ prolactin were performed by the method reported (Ota 1983). Prolactin receptors from liver homogenates showed the highest binding $30 \mathrm{~min}$ after onset of incubation (Ota 1983). The specific bindings of the hormones were calculated by subtracting nonspecific binding from total binding and expressed as fmole $/ \mathrm{mg}$ homogenate protein. Nonspecific bindings of the LH, FSH and prolactin receptors were less than 3.0, 2.7 and $3.8 \%$ of the total bindings, respectively. The protein concentration in the receptor fractions were measured by the method of Lowry et al. (1951) with BSA as standard.

For the kinetic study of the receptors, the ovarian homogenates from some of the patients were incubated with the constant amount $(40,000 \mathrm{cpm} / 100 \mu \mathrm{l})$ of the labeled hormones and the increasing amount of the unlabeled hormones (hCG, oFSH or oPRL). The obtained results were analyzed by Scatchard plots (Scatchard 1949) to determine the association constants $(\mathrm{Ka})$ and maximal binding capacities (sites; Bm). Because of scarcity of the materials obtained from the individual in the operation, it was difficult to calculate the association constant and maximal binding site with each patient.

\section{Radioimmunoassays for $L H$ and FSH in serum}

Determinatin of serum LH and FSH was performed with RIA kits obtained from Daiichi Radioisotope Laboratories (Tokyo) according to the method reported by Kusuda et al. (1973).

\section{Radioimmunoassays for estrone, estradiol and testosterone in serum}

Serum estrone and estradiol levels were determined by using kits obtained from Teikoku Hormone MFG Co. (Tokyo). The assay procedures were described elsewhere (Kanbegawa 1975).

Testosterone levels were estimated by RIA kit obtained from Eiken Co. (Tokyo). The characteristics and standardization of this assay have been reported previously (Arai et al. 1979).

\section{Statistics}

All results were expressed as the mean \pm s.E. of 6 to 9 samples. Experimental data were analyzed using analysis of variance and Duncan's new multiple range test. A value of $p<$ 0.05 was chosen as the limit of statistical significance.

\section{RESUlts}

LH, FSH and prolactin receptors during the late follicular and midluteal phases, and in polycystic ovary patients

Table 1 shows the ovarian receptors and serum hormone levels during the normal menstrual cycles and in PCO patients. Ovarian LH receptors maintained a low binding level $(1.73 \pm 0.14$ fmole $/ \mathrm{mg}$ homogenate protein) in the LF phase $(p<0.01)$, then increased about 3 -fold in the ML phase $(p<0.01)$. Scatchard analyses of the binding data revealed that the association constants of the LH receptor obtained from the $\mathrm{LF}$ and ML ovaries were 2.2 and $1.8 \times 10^{10} \mathrm{M}^{-1}$, 
TABLE 1. Levels of serum gonadotropin and steroid hormones and the receptors for gonadotropins and prolactin in polycystic ovaries

\begin{tabular}{|c|c|c|c|c|c|c|c|c|c|}
\hline & Patient & $\begin{array}{c}\text { LH } \\
\text { receptors } \\
\text { fmole/mg } \\
\text { homogenate } \\
\text { protein }\end{array}$ & $\begin{array}{c}\text { FSH } \\
\text { receptors } \\
\text { fmole/mg } \\
\text { homogenate } \\
\text { protein }\end{array}$ & $\begin{array}{c}\text { PRL } \\
\text { receptors } \\
\text { fmole/mg } \\
\text { homogenate } \\
\text { protein }\end{array}$ & $\begin{array}{c}\mathrm{LH} \\
(\mathrm{mIU} / \mathrm{ml})\end{array}$ & $\begin{array}{c}\text { FSH } \\
(\mathrm{mIU} / \mathrm{ml})\end{array}$ & $\begin{array}{l}\text { Estrone } \\
(\mathrm{pg} / \mathrm{ml})\end{array}$ & $\begin{array}{c}17 \beta \text {-estradiol } \\
(\mathrm{pg} / \mathrm{ml})\end{array}$ & $\begin{array}{l}\text { Testosterone } \\
\quad(\mathrm{ng} / \mathrm{ml})\end{array}$ \\
\hline \multirow[t]{2}{*}{1} & M.M. (rt) & 3.73 & 1.96 & 272 & \multirow{2}{*}{50.6} & \multirow{2}{*}{10.8} & \multirow{2}{*}{136} & \multirow{2}{*}{59} & \multirow{2}{*}{2.1} \\
\hline & (lt) & 2.09 & 4.19 & 174 & & & & & \\
\hline 2 & K.K. & 5.10 & 4.25 & 142 & 40.1 & 12.9 & 129 & 65 & 1.4 \\
\hline 3 & Y.M. & 1.37 & 4.41 & 101 & 65.1 & 14.1 & 196 & 149 & 2.5 \\
\hline 4 & Y.T. & 5.32 & 3.91 & 194 & 21.9 & 9.6 & N.M. & N.M. & 1.6 \\
\hline 5 & Y.I. & 2.96 & 4.44 & 221 & 44.6 & 8.5 & 49 & 36 & N.M. \\
\hline \multirow[t]{2}{*}{6} & A.O. (rt) & 7.07 & N.D. & 150 & \multirow{2}{*}{17.0} & \multirow{2}{*}{14.9} & \multirow{2}{*}{84} & \multirow{2}{*}{29} & \multirow{2}{*}{1.2} \\
\hline & (lt) & 2.21 & 3.02 & 87 & & & & & \\
\hline 7 & I.K. & 4.74 & 1.68 & 121 & 36.4 & 13.2 & 93 & 55 & 1.5 \\
\hline \multicolumn{2}{|c|}{ Mean } & $3.84 \pm 0.62$ & $3.26 \pm 0.42$ & $162 \pm 60$ & $39.4 \pm 6.2$ & $12.0 \pm 0.9$ & $115 \pm 21$ & $66 \pm 18$ & $1.7 \pm 0.2$ \\
\hline \multicolumn{2}{|c|}{$\begin{array}{r}\text { Late follicular } \\
\quad \text { level }(n=6)\end{array}$} & $1.73 \pm 0.14$ & $4.09 \pm 0.40$ & $156 \pm 43$ & $17.1 \pm 2.9$ & $12.1 \pm 1.5$ & $78 \pm 9$ & $105 \pm 26$ & $0.9 \pm 0.3$ \\
\hline \multicolumn{2}{|c|}{$\begin{array}{l}\text { Midluteal } \\
\quad \text { level }(n=6)\end{array}$} & $4.96 \pm 0.64$ & $0.93 \pm 0.51$ & $175 \pm 58$ & $13.5 \pm 3.1$ & $10.8 \pm 1.1$ & $79 \pm 13$ & $73 \pm 14$ & $0.8 \pm 0.2$ \\
\hline
\end{tabular}

N.M., not measured ; N.D., not detectable ; rt, right ovary ; lt, left ovary. 
respectively. LH receptor binding in $\mathrm{PCO}$ cases was $3.84 \pm 0.62 \mathrm{fmole} / \mathrm{mg}$ homogenate protein in average, which was significantly higher than the LF level $(p<0.05)$ as shown in the Table. It is noteworthy that $\mathrm{LH}$ receptors of the bilateral ovaries obtained from identical patients (M.M. and A.O.) exhibited the levels different from each other. Kinetic analysis of the receptor from patient K.K. showed a single class of the binding site with the association constant of $1.9 \times 10^{10} \mathrm{M}^{-1}$.

Ovarian FSH receptors in the LF phase was much higher than those in the ML phase, which was only $23 \%$ of the former $(p<0.01)$. The association constant of FSH receptors from LF and ML ovaries were 5.2 and $6.0 \times 10^{10} \mathrm{M}^{-1}$. FSH receptors in $\mathrm{PCO}$ showed a much higher level $(3.26 \pm 0.42 \mathrm{fmole} / \mathrm{mg}$ homogenate protein) than the ML level $(p<0.01)$ and was close to the LF level. It should also be noted that the FSH receptor bindings of the bilateral ovaries from the same patients (M.M. and A.O.) showed different levels from each other. The association constants of FSH receptors from patients Y.M. and Y.I. averaged $6.0 \times$ $10^{10} \mathrm{M}^{-1}$.

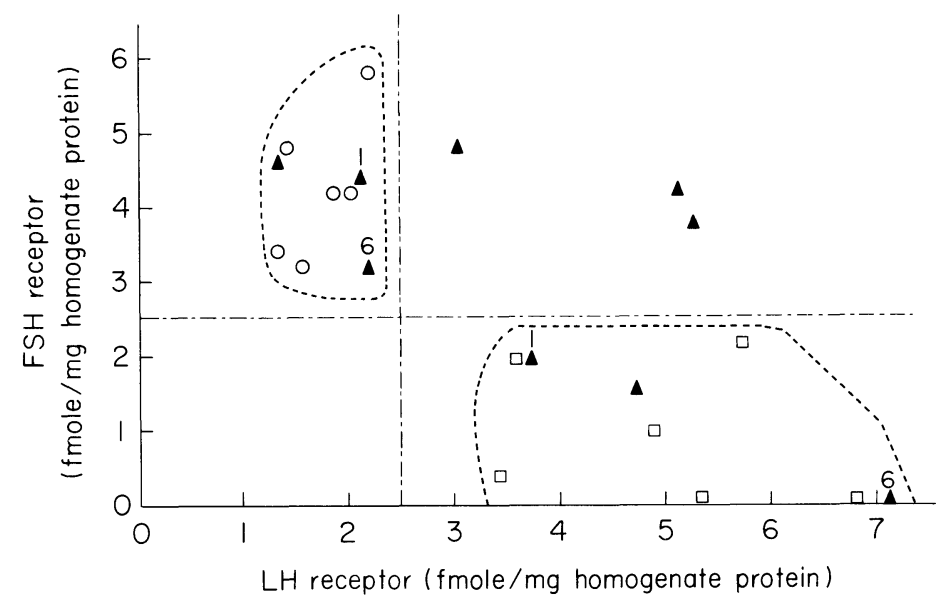

Fig. 1. Correlation between LH and FSH receptors during the normal menstrual cycles of the late follicular $(n=6)$ and midluteal $(n=6)$ phases and in the seven PCO cases. Individual levels of $\mathrm{LH}$ receptors were plotted against those of FSH receptors. The values were expressed as fmole of specifically bound hormone to the receptor per mg homogenate protein. The symbols indicate the receptor binding from normal subjects in the late follicular phase $(\bigcirc)$ and in the midluteal phase $(\square)$, and from the PCO patients $(\Delta)$. The symbols with number in the PCO group indicate the receptor levels of the bilateral ovaries from the same patients (No. 1: M.M. and No. 6: A.O.). The area circled with a broken line in the left upper portion ( $\mathrm{LH}$ receptor $\leqq 2.5$ fmole/mg protein, FSH receptor $\geqq 2.5$ fmole $/ \mathrm{mg}$ protein) indicates the range of the both receptors in the late follicular phase and that circled with a broken line in the right lower portion ( $\mathrm{LH}$ receptor $\geqq 2.5$ fmole $/ \mathrm{mg}$ protein, FSH receptor $\leqq 2.5 \mathrm{fmole} / \mathrm{mg}$ protein) shows that in the midluteal phase. 
Prolactin receptor binding was $156 \pm 43 \mathrm{fmoles} / \mathrm{mg}$ homogenate protein in the $\mathrm{LF}$ phase and increased slightly in the ML phase. Prolactin receptor binding in PCO cases was almost the same level as the LF level. The association constant of prolactin receptors from patient Y.T. was $6.9 \times 10^{10} \mathrm{M}^{-1}$ and there was no difference from the controls.

\section{Correlation between $L H$ and FSH receptors in polycystic ovary patients}

To study the correlation between the bindings of $\mathrm{LH}$ and FSH receptors, individual values of $\mathrm{LH}$ receptors were plotted against those of FSH receptors as shown in Fig. 1. Interestingly, the individual values in the LF phase were collectively plotted in the left upper portion and those in the ML phase were in the right lower portion. These findings indicate that in the LF phase FSH receptors increase and $\mathrm{LH}$ receptors decrease. In turn, in the ML phase the both receptor levels become reverse. On the other hand, in PCO approximately half cases examined (3/7) showed high levels in the both receptors. Moreover, a characteristic mode of receptor bindings was observed in the two cases, which were analyzed with bilateral ovaries. That is, if one side of the ovaries showed a low binding in $\mathrm{LH}$ receptors and a high binding in FSH receptors, which was observed in the LF phase, the other side showed an opposite result, which was observed in the ML phase.

Serum hormone levels during the late follicular and midluteal phases, and in polycystic ovary patients

Serum LH level in the PCO patients was significantly elevated over the both controls (LF and ML groups ; $p<0.05$ and 0.01) as shown in Table 1. Serum FSH level, however, was almost the same among these three groups. On the other hand, serum estrone level in the PCO group was well-maintained and slightly higher than the controls, but the estradiol level was insignificantly lower than the LF level. Thus, estrone to estradiol ratio in the PCO group was greater than 1.0. While, the ratio in the LF phase was smaller than 1.0 and was almost 1.0 in the

TABLE 2. Correlation coefficients between the receptors and serum hormone levels in polycystic ovaries

\begin{tabular}{lcccc}
\hline \multirow{2}{*}{ Serum hormone } & \multirow{2}{*}{$\begin{array}{c}\text { No. of } \\
\text { ovaries }\end{array}$} & \multicolumn{3}{c}{ Receptor } \\
\cline { 3 - 5 } & & LH & FSH & Prolactin \\
\hline LH & 8 & $-0.770^{*}$ & 0.503 & 0.200 \\
FSH & 8 & -0.096 & 0.446 & $-0.780^{*}$ \\
Estradiol & 7 & -0.140 & 0.570 & 0.386 \\
Estrone & 7 & -0.380 & 0.269 & -0.415 \\
Testosterone & 6 & 0.592 & 0.555 & -0.201 \\
\hline
\end{tabular}

${ }^{*} p<0.01$ 
ML phase. Serum testosterone level in the PCO group was significantly higher than the both controls $(p<0.05)$.

Correlation coefficients between the receptors and serum hormone levels in polycystic ovary patients

In order to elucidate the relationship between the receptors and serum hormone levels, a correlation coefficients between the values of hormones and receptors were calculated as shown in Table 2 . LH receptors tended to exhibit a negative correlation against several serum hormone levels except that of testosterone. This negative correlation was only significant between serum LH and its receptors $(p<0.01)$. On the other hand, FSH receptors tended to show a positive correlation with every hormone levels examined, although the values were not significant. Prolactin receptors negatively correlated with serum FSH level $(p<$ $0.01)$.

\section{Discussion}

The LH receptor in human ovary increases in accordance with follicular maturation, then drops transiently at postovulatory days and again rises, finally coming up to the highest level in the luteal phase (Wardlaw et al. 1975; Rajaniemi et al. 1981). In the present study the LH receptor in the ML phase was $287 \%$ of that in the LF phase, which was compatible with other investigators (Wardlaw et al. 1975; Rajaniemi et al. 1981). In the PCO group, the binding sites for $\mathrm{LH}$ increased to $225 \%$ of those in the LF phase, close to those in the ML phase. It is generally agreed that $\mathrm{LH}$ in serum used to down-regulate its ovarian receptors, as other investigators described (Conti et al. 1977). In the PCO group serum LH level was much higher than that of the LF phase ( 2.3 fold), in which the normal ovary shows the lowest binding of LH receptors. This indicates that the down-regulation mechanism of the $\mathrm{LH}$ receptor by the homologous hormone would not work properly in PCO. The LH receptor in some mammals is known to be modulated by several hormones such as FSH (Casper and Erickson 1981), prolactin (Holt et al. 1976; Richards and Williams 1976), estrogen (Uilenbroek and Richards 1979) and androgen (Knecht et al. 1984), not only by LH (hCG ; Richards and Williams 1976; Conti et al. 1977). Therefore, it is possible that the LH receptor in human ovary may be regulated with those hormones. Especially, high level of androgen or well-maintained level of serum estrone may work on the $\mathrm{LH}$ receptor upward in PCO.

The relatively high level of the LH receptor binding in human PCO appears comparable to that in the rat. Ota et al. (1982a) presented that in PCO rats induced by testosterone propionate the ovarian $\mathrm{LH}$ receptor binding was as high as that at diestrus or proestrus. Rajaniemi et al. (1980) however reported that the LH receptor in PCO patients was significantly reduced less than the level of the control preovulatory follicle, which is different from the present findings. 
The ovarian FSH receptor binding from individuals with the normal menstrual cycles showed a high level in the LF phase and a low level in the ML phase as shown in the results. It should be noticed that the FSH receptor in PCO was much elevated, which was close to the LF level. Some explanation could be tentatively stated herein. The level of serum FSH in the syndrome may act on the ovary to induce FSH receptors, and well-maintained estrone level could be considered as one of the stimulatory factors, since estrogen enhances the binding of FSH receptors in rat ovary in vivo and in vitro (Ireland and Richards 1978; Knecht et al. 1984).

The activated level of FSH receptors in human PCO is compatible with that observed in the animal experiment as we have described previously (Ota et al. 1982a). In PCO rats induced by testosterone propionate the ovarian FSH receptor binding was markedly higher than the level at proestrus, which was the highest during the estrous cycle. Meanwhile, Copmann and Adams (1981) also found a well-maintained level of FSH receptors in PCO rats produced by daily injection of hCG as compared with control levels. The markedly elevated level of the receptor appears to be responsible for one of the triggers which develope PCO syndrome. High incidence of ovarian hyperstimulation in this syndrome may be explained by the fact of the high level of FSH receptors. Thus, the elevated level of the receptor would induce too much response of ovary during hormone stimulation and eventually lead to the ovarian hyperstimulation.

In the ovary, the regulatory mechanism of prolactin receptors is poorly understood. The prolactin receptor in rat ovary was shown to have cyclic changes of the binding sites during the estrous cycle (Kelly et al. 1975; Cheng 1976; Solano et al. 1980). In the previous study (Ota et al. 1982b) the ovarian prolactin receptor binding showed the highest level at metaestrus and the lowest at estrus. In human ovaries, there was no significant difference of the bindings of prolactin receptors between the LF and ML phases. The prolactin receptor in PCO group is almost the same as those with the both controls.

The prolacin receptor is generally considered to be upward by the homologous hormone in rat liver or ovary (Posner et al. 1975; Bohnet and Friesen 1976), which is different from regulation of LH or FSH receptors (Conti et al. 1977; Ireland and Richards 1978). It is interesting that a strong negative correlation was observed between the prolactin receptor and serum FSH level. It seems to be possible to explain this finding as follows: serum FSH may have some influence, at least indirectly through steroid hormones, on the prolactin receptor, as Hammond and Krall (1979) already described that steroid hormones such as estrogen, progesterone or testosterone could modulate prolactin receptors in an increasing fashion in cultured porcine granulosa cells in vitro.

In conclusion, PCO patients maintained the high levels of ovarian receptors for LH and FSH. A lack of the down-regulation mechanism of the $\mathrm{LH}$ receptor in spite of the high level of serum LH might be one of the clues to solve the 
pathogenesis of PCO syndrome. Elevated level of FSH receptors could explain high sensitivity during hormone stimulation and one of the causes of the liability to ovarian hyperstimulation.

\section{Acknowledgments}

Thanks are due to Ms. Mizue Itoh for her skillful technical assistance. This research was supported by Grand-in-Aid for Scientific Research from the Ministry of Education of Japan.

\section{References}

1) Arai, Y., Demura, R. \& Demura, H. (1979) Basic and clinical evaluation of ${ }^{125}$ I-testosterone radioimmunoassay kit "Eiken". Clin. Endocr., 27, 527-531. (Japanese)

2) Bohnet, H.G. \& Friesen, H.G. (1976) Effect of prolactin and growth hormone on prolactin and LH receptors in the dwarf mouse. J. Reprod. Fertil., 48, 307-311.

3) Casper, R.F. \& Erikcson, G.F. (1981) In vitro heteroregulation of LH receptors by prolactin and FSH in rat granulosa cells. Molec. cell. Endocr., 23, 161-171.

4) Cheng, K.W. (1976) Changes in rat ovaries of specific binding for LH, FSH and prolactin during the oestrous cycle and pregnancy. J. Reprod. Fertil., 48, 129-135.

5) Conti, M., Harwood, J.P., Dufau, M.L. \& Catt, K.J. (1977) Regulation of luteinizing hormone receptors and adenylate cyclase activity by gonadotropin in the rat ovary. Molec. Pharmacol., 13, 1024-1032.

6) Copmann, T.L. \& Adams, W.C. (1981) Ovarian gonadotropin receptors during experimental ovarian cyst formation in the rat. Biol. Reprod., 25, 115-119.

7) Dawood, M.Y. \& Saxena, B.B. (1978) Circulating pituitary-gonadal hormones in clomiphene-induced cycles. Obstet. and Gynec., 52, 445-450.

8) Falaschi, P., Del Pozo, E., Rocco, A., Toscano, V., Petrangeli, E., Pompei, P. \& Frajese, G. (1980) Prolactin release in polycystic ovary. Obstet. and Gynec., 55, 579-582.

9) Fraker, P.J. \& Speck, J.C., Jr. (1978) Protein and cell membrane iodinations with a sparingly soluble chloroamide, 1, 3, 4, 6-tetrachloro-3a, 6a-diphenylglycoluril. Biochem. biophys. Res. Commun., 80, 849-857.

10) Fukushima, M. \& Ota, H. (1981) Polycystic ovary and hyperprolactinemia : Problems with the induction of ovulation and management of the patients during pregnancy. Jap. J. Fertil. Steril., 26, 561. (Japanese)

11) Hammond, J.M. \& Krall, E. (1979) Steroid hormones modulate prolactin binding by cultured porcine granulosa cells. Biochem. biophys. Res. Commun., 91, 284-288.

12) Holt, J.A., Richards, J.S., Midgley, A.R., Jr. \& Reichert, L.E., Jr. (1976) Effect of prolactin on LH receptor in rat luteal cells. Endocrinology, 98, 1005-1013.

13) Ireland, J.J. \& Richards, J.S. (1978) Acute effects of estradiol and folliclestimulating hormone on specific binding of human $\left[{ }^{125} \mathrm{I}\right]$ iodo-follicle-stimulating hormone to rat ovarian granulosa cells in vivo and in vitro. Endocrinology, 102, 876883.

14) Kanbegawa, A. (1975) Estrogen. Saishin Igaku, 30, 790-798. (Japanese)

15) Kelly, P.A., Posner, B.J. \& Friesen, H.G. (1975) Effects of hypophysectomy, ovariectomy and cycloheximide on specific binding sites for lactogenic hormones in rat liver. Endocrinology, 97, 1408-1415.

16) Knecht, M.L., Darbon, J-M., Ranta, T., Baukal, A.J. \& Catt, K. J. (1984) Estrogens enhance the adenosine $3^{\prime}, 5^{\prime}$-monophosphate-mediated induction of folliclestimulating hormone and luteinizing hormone receptors in rat granulosa cells. 
Endocrinology, 115, 41-49.

17) Kusuda, M., Nakamura, M. \& Onoue, T. (1973) Measurement of serum FSH and LH by the double antibody radioimmunoassay. World Obstet. Gynec., 25, 543-551. ('apanese)

18) Lowry, O.H., Rosebrough, N.J., Farr, A.L. \& Randall, R.L. (1951) Protein measurement with the folin phenol reagent. J. biol. Chem., 193, 265-275.

19) Ota, H. (1983) Study on the pathophysiology in polycystic ovary syndrome. Thesis for the Department of Obstetrics and Gynecology, Akita University. (in Japanese with English abstract)

20) Ota, H., Fukushima, M., Ichinoseki, K. \& Suzuki, M. (1979) Prolactin secretion in polycystic ovary syndrome. Acta obstet. gynec. jap., 31, 2027. (abstract)

21) Ota, H., Wakizaka, A., Fukushima, M. \& Maki, M. (1982a) Activation of the LH and FSH receptors in the testosterone-induced polycystic ovary in rats. IRCS med. Sci., 10, 914-915.

22) Ota, H., Wakizaka, A., Fukushima, M. \& Maki, M. (1982b) Changes during the estrous cycle in ovarian receptors for LH, FSH and prolactin and in hepatic receptor for prolactin in rat. IRCS med. Sci., 10, 976-977.

23) Ota, H., Fukushima, M., Maki, M., Murata, J. \& Wakizaka, A. (1984) Ovarian gonadotropin and prolactin receptor activities in patients with polycystic ovarian syndrome. IRCS med. Sci., 12, 117-118.

24) Posner, B.I., Kelly, P.A. \& Friesen, H.G. (1975) Prolactin receptors in rat liver : Possible induction by prolactin. Science, 188, 57-59.

25) Rajaniemi, H.J., Rönnberg, L., Kauppila, A., Ylöstalo, P. \& Vihko, R. (1980) Luteinizing hormone receptors in ovarian follicles of patients with polycystic ovarian disease. J. clin. Endocr. Metab., 51, 1054-1057.

26) Rajaniemi, H.J., Rönnberg, L., Kauppila, A., Ylöstalo, P., Jalkanen, M., Saastamoinen, J., Selander, K., Pystynen, P. \& Vihko, R. (1981) Luteinizing hormone receptors in human ovarian follicles and corpora lutea during menstrual cycle and pregnancy. J. clin. Endocr. Metab., 52, 307-313.

27) Richards, J.S. \& Williams, J.J. (1976) Luteal cell receptor content for prolactin (PRL) and luteinizing hormone (LH). Regulation by LH and PRL. Endocrinology, 99, 1571-1581.

28) Scatchard, G. (1949) The attractions of proteins for small molecules and ions. Ann. N.Y. Acad. Sci., 51, 660-672.

29) Solano, A.R., Garcia, Vela, A., Catt, K.J. \& Dufau, M.L. (1980) Regulation of ovarian gonadotropin receptors and LH bioactivity during the estrous cycle. FEBS letters, 122, 184-188.

30) Thorner, M.O. (1977) Prolactin. Clin. Endocr. Metab., 6, 201-222.

31) Tzingounis, V.A., Aksu, M.F. \& Tsoukalos, S.G. (1979) Hyperprolactinemia and polycystic ovarian syndrome. Int. J. Fertil., 24, 276-280.

32) Uilenbroek, J. Th. J. \& Richards, J.S. (1979) Ovarian follicular development during the rat estrous cycle: Gonadotropin receptors and follicular responsiveness. Biol. Reprod., 20, 1159-1165.

33) Wardlaw, S., Lauersen, N.H. \& Saxena, B.B. (1975) The LH-hCG receptor of human ovary at various stages of the menstrual cycle. Acta endocr., 79, 568-576.

34) Wortzman, J. \& Hirschowitz, J. (1980) Galactorrhea and hyperprolactinemia during treatment of polycystic ovary syndrome. Obstet. and Gynec., 55, 460-463. 